\title{
An Inferential Study on the Profitability Determinants of the Cement Industry in Bangladesh
}

\author{
Sonia Rezina \\ Assistant Professor \\ School of Business \\ Uttara University \\ Dhaka, Bangladesh \\ E-mail:rezina.sonia@gmail.com \\ Aysha Ashraf \\ Assistant Professor in Finance \\ Asian University of Bangladesh \\ Dhaka, Bangladesh \\ E-mail:ayshadu94@gmail.com \\ Md. Atiqullah Khan \\ Independent Researcher \\ Dhaka, Bangladesh \\ E-mail:writetoatiq@gmail.com
}

Received: June 29, 2020

doi: I0.4628I/asfbr.v4i2.684
Accepted: July 23, 2020

Online Published: July 30, 2020

URL: https://doi.org/I0.4628I/asfbr.v4i2.684

\begin{abstract}
This paper examines the impacts of firm-specific and macroeconomic factors in determining the profitability of the cement industry in Bangladesh. This study took stock exchange listed all cement companies of Bangladesh as samples and covered the period of 2000-2018. Return on Assets (ROA) was chosen as the dependent variable and firm size, expense to revenue ratio, leverage, age, inflation rate, GDP growth rate, and real interest rate were chosen as independent variables where the first four are firm-specific and the other three are macroeconomic factors. This study considered ROA as the profitability measurement of the firms. The study found that leverage, GDP growth rate, and real interest rate have significant impacts on the profitability. Firm size, age, GDP growth rate, and real interest rate have a positive impact whereas expenses to revenue ratio, leverage, and inflation have a negative impact on the profitability of the firms under the cement industry.
\end{abstract}

Keywords: Firm Variables, Macroeconomic Variables, Cement Industry, Profitability, Bangladesh.

\section{Introduction}

Cement industry is said to have a fundamental contribution to the infrastructural development of any country. In the world of the cement market, Bangladesh's current position is fortieth but the country has huge potential in the days ahead as I4 companies are exporting cement into different countries and the market is on growth where until the first half of the I990s, around $95 \%$ of total demand for cement in Bangladesh was covered by imports (Tuhin, 2019).

In the last 7 years, the cement industry of Bangladesh grew at almost I1.5\% CAGR (Compound Annual Growth Rate) due to the doubling of demand from I4.5 million metric tons per year to almost 3I million metric tons per year with the cooperation of the government, several multinational manufacturers and local entrepreneurs entered the industry in the late 1990s (EBL Securities Ltd., 2019).

At present, Bangladesh cement industry is operated by the leading global performers like Lafarge (France), Holcim (Switzerland) along with 30 other local and Multinational manufacturers (Cement in Bangladesh: Building a Concrete Future Light Castle Partners, 2020). Dhaka Stock Exchange (DSE) is currently enlisted with seven cement companies (Company Listing by Industry, 2020). 
With a decent growth rate on average, there was a comprehensive advancement in Bangladesh in the last couple of years and the country is expecting to maintain growth above $7 \%$ in the years ahead (The Daily Star, 2019).

According to a recent forecast by HSBC, Bangladesh will be the biggest mover in the global GDP product rankings in 2030 and its economy may jump I6 notches and that will make the country become the 26th largest economy in the world (Rahman, 2018). Up to the year 2030, the country is also expected to have the highest yearly real GDP growth of 7.I percent and the economy size to be expanded by 2.5 times from USD 300 Billion to USD 700 Billion in the interim (Rahman, 20I8).

Bangladesh is facing a massive requirement for basic infrastructure, housing, and services to support its tremendous economic activities, which has put the market in high demand for cement. In recent years; cement demand is massively increasing to contribute the megaprojects.

Bangladesh has undertaken some large infrastructure projects to upkeep its huge economic growth. 7 mega infrastructure projects including bridges, rail lines, power plants, and a metro rail have been allotted with more than USD 3.5 billion in FY2019 (Cement in Bangladesh: Building a Concrete Future - Light Castle Partners, 2020).

Budget allocation to transportation and communication system has faced immense growth over time and therefore, the contribution of the development projects of the government towards the demand for cement has been identified as the highest in recent years overtaking the contribution of individual home-builders. Additionally, an export target of USD I0.50 million has been set by the Export Promotion Bureau (EPB) for the FY 2019-20 (Bangladesh revises export target for cement in FY20, 2019).

Because of the swift momentum of industrialization, urbanization, large-scale infrastructural and government development projects, and also the construction of several residential and commercial structures; there occurred remarkable growth in market demand. This trend is anticipated to be sustained in the upcoming years. Profitability is a measure of firms' performance. Thus the factors influencing the profitability of the firms under cement industry is a topic of investigation.

A firm's performance and success are measured by its profitability. Thus a manager's prime objective is to maximize the profits of a firm. Stakeholders' value and investors' value are also maximized by profitability. Researchers have conducted numerous studies on profitability and its major determinants. The past literature study mainly considered the firm-specific and macroeconomic determinants of profitability.

Agustinus and Rachmadi (2008) reviewed the factors influencing the corporate performance of Indonesia before and after the 1997 financial crisis. Employing Ordinary Least Square (OLS), an empirical analysis covering the period of 1994-2004 of the Jakarta Stock Exchange (JSX) consisting of panel data of the 238 listed companies showed a greater influence of macrofactors than firm-specific factors on company performance due to the 1997 great crisis. Moreover, the study also revealed a positive relationship exists between firm size and profitability.

Hassan and Muniyat (2019) focused on a study that takes a random sample of five listed pharmaceutical companies and covers the period 2008-20I7. The research method for the study is a panel analysis where ROA (Return on assets) was used as a measure of profitability. They found that expense to revenue, and company sizes have a significant correlation with profitability which was negative. Besides, they found a significant correlation between GDP growth and profitability which was positive. Additionally, inflation rate, and profitability have a significant negative relationship.

This paper thoroughly studied the effects of firm-specific and macroeconomic factors on the profitability of the cement industry in Bangladesh. Firm size, the expense to revenue, leverage, and age were considered as a set of firm-specific determinants related to profitability. GDP growth rate and real interest rate were considered as the other set of macroeconomic variables which discuss profitability in the macroeconomic environment within which the cement industry operates.

\section{I.IObjectives of the Research}

- To identify the most relevant factors influencing the cement industry's profitability in Bangladesh.

- To show the influence of different firm level and macroeconomic level factors on Return on Assets (ROA) of the cement industry in Bangladesh.

- To determine the association between firm-specific and macroeconomic factors on the profitability of the cement industry in Bangladesh.

\section{Review of Literature}

According to Aparna (2015), the efficiency of fund utilization by a firm is indicated by its high profit. Bashar and Islam (20I4) elaborated that, profitability indicates the capacity of a firm to gain profit after deducting the operating expenses, interest on debt, and taxes from the sales revenue.

Pratheepan (2014) mentioned that, for an export-oriented country, determinants of profitability are the essential elements for economic survival. He discovered a significant positive relationship between firm size and profitability and a negative relationship with leverage but that was not statistically significant in his study of Sri Lankan manufacturing companies. On the other hand, Aparna (2015) showed a negative relationship between profitability and firm size, leverage, and productivity in the case of the Steel Authority of India (SAIL).In their study of Philippine banks, Sufian and Chong (2008) found that a 
bank's profitability is negatively affected by the size, credit risk, and expense preference behavior, while positively affected by non-interest income and capitalization.

Al-Jafari and Samman (2015) found a positive association of firm size, fixed assets, growth, and working capital on profitability which was significant and a negative association between profitability and financial leverage for the industrial firms in Oman. Maroa and Kioko (2016) found that there exists significant positive relationship between liquidity, firm size, and profitability whereas an insignificant positive relationship is experienced between leverage and profitability.

Sivathaasan, Tharanika, Sinthuja, and Hanitha (2013) looked into the relationship of capital structure, firm size, working capital, growth rate, and non-debt tax shield with the profitability of the Sri Lankan manufacturing companies. They found that profitability is significantly related to capital structure and non-tax shield, whereas it has no significant relationship with firm size.

A study of Malaysian construction companies conducted by Zaid, Wan Mud, and Zulqernain (2014) came with a result of a positive association among firm size, liquidity on the profitability which was significant.

After analyzing the foreign and local banks in Ghana, Gyamerah and Amoah (2015) found that cost management and profitability have a significant negative relationship while bank size and credit risk have a significant positive relationship with profitability. Additionally, the study by Prempeh, Sekyere, and Amponsah Addy (2018) on the manufacturing firms of the said country stated that leverage and interest rates have a negative relationship with profitability while liquidity and firm size have a significantly positive relationship with profitability. Moreover, tangibility and GDP have shown no significant relationship with profitability.

Egbunike and Okerekeoti (2018) explored that, in the case of Nigerian manufacturing firms, firm size, leverage, and liquidity have a positive relationship with profitability which was significant. Furthermore, after studying the macroeconomic variables, they found a positive correlation between GDP growth and profitability, but a negative correlation between inflation rate and profitability, both of which were significant. The researchers didn't find any significant impact on interest rate and exchange rate. Highlighting the Nigerian economy, another study by Ehi-Oshio, Adeyemi, and Enofe (2013) found that, firm size and financial leverage have a positive relationship with corporate profitability.

Prasetyantoko and Rachmadi (2008) disclosed a bigger impact of macro-factors than firm-level factors on the corporate performance of Indonesian firms, probably due to the 1997 great crisis. Additionally, this study discovered a positive relationship between firm size and profitability. Khan, Shamim, and Goyal (2008) explored that firm size and growth have a positive association and leverage has a negative association with profitability in the Indian telecom industry.

Vatavu (2014) examined that tangibility, business risk, inflation rate, financial crisis, and the level of taxation are negatively related to profitability, and liquidity is positively related to the same in the context of Romanian companies.

Age, as a firm-specific factor, got attention from many researchers, such as (Coad, Segarra-Blasco, \& Teruel, 20I0; Hirsch \& Hartmann, 20I4; Pervan \& Curak, 2016), identified a signal of a decline in profitability as the firm's age increases. On the contrary, Majumdar (1997) found that a firm's size and age are positively related to its productivity and profitability.

Pervan, Pervan, and Curak (2019) came up with a positive relationship of age and inflation rate with the profitability of the Croatian manufacturing industry. Some of the few pioneers to study on the firm performance based on firm-specific and industry-specific effects are Schmalensee (1985), Hansen and Wernefelt (I989), and Mauri and Michaels (I998). These subjects have also been examined by Akben-Selcuk (2016), Mirza and Javed (20I3), Dogan (20I3), Tailab (20I4), Al-Jafari and Samman (2015), and Batra and Kalia (2016) in the recent years.

Researchers conducted various studies to identify the association of firm size with profitability. Some of them are Fukao (2006), Asimakopoulos, Samitas and Papadogonas (2009), Nunes, Serrasqueiro, \& Sequeira (2009), Stierwald (2010), Yazdanfar (20I3), Zaid et al. (2014), and Pratheepan (20I4).

In their Pecking Order Theory, Myers and Majluf (1984) explained that leverage is inversely related to profitability. This view has also been confirmed by Kester (1986), Titman and Wessels (1988), Rajan and Zingales (I995), Samarakoon (1999), Booth, Aivazian, Demirgusc-Kunt, and Maksimovic (200I), and Al-Jafari and Samman (2015). On the contrary, Ifeduni and Charlse (2018) found higher profitability because of higher gearing (debt).Expense to revenue ratio has significant negative impact on profitability found by Burja (20I I).

In contrast, the trade-off, free cash flow (Jensen, 1986), signaling, and agency theories, showed the existence of a positive relationship between leverage and profitability, which was later been confirmed by the study of Sivathaasan et al. (20I3).

In the paper of Nanda and Panda (2018), it has been found that corporate profitability is mostly affected by various firm-level elements, namely firm size, liquidity, leverage, etc. rather than the macroeconomic indicator. After researching the Indian corporate sector from the circumstance of the pre and post-crisis performances, they found a positive association between firm size and profitability. The findings were similar to the studies conducted by Nunes et al. (2009), Asimakopoulos et al. (2009), Stierwald (2010), Yazdanfar (2013), and Pratheepan (2014). This was said to be the result of economies of scale. This study also found a negative relationship between leverage and profitability which was significant, like the study conducted by Nunes et al. (2009). 
Demir (2007) showed that the real interest rate has a significant negative impact on the profitability of the manufacturing industry. But Alper and Anbar (20II) found that the real interest rate affects the performance of banks positively.

All of the above findings and pieces of evidence are the perspective from foreign countries, whereas, we have found very few studies focusing on the above-mentioned aspect from the context of manufacturing companies from Bangladesh and the cement industry to be specific.

Nevertheless, this study addressed various factors which seemed to have a substantial influence on profitability; and also considered the fact that, due to inefficient market and change of time, risk factor also changes. Moreover, certain factors affect the profitability of manufacturing companies of Bangladesh in particular, such as the size of the firm, the expense to revenue ratio, maintaining leverage in capital structure, and learning effect over the age of business operations as firm-specific factors and inflation, GDP growth rate, and real interest rate as macroeconomic factors. Therefore, the research was necessary to reveal the above factors. The paper has presented the impact of control variables on the dependent variable (ROA). In addition to that, it also exhibited the coefficient of determination among seven independent variables on the dependent variable. This study has been attempted to report this gap.

\section{Research Methodology \\ 3.I Data and Variables}

All the companies listed under the cement industry on DSE (Dhaka Stock Exchange) have been chosen for conducting this study. The data period for conducting the study has been chosen for the last 19 years (2000-2018) and the total no. of observations for the study is I06. The dataset is an unbalanced panel dataset as some companies listed on the stock exchange in later years. Macroeconomic data were collected from World Bank portal (The World Bank Data, 2020). Firm-specific data were collected from the annual reports of the companies.

\subsection{Dependent Variable}

- ROA: ROA (Returns on Assets) has been chosen in this study as the dependent variable for measuring profitability. According to conducted studies, ROA is a better estimation of profitability as it also considers financial leverage. Through ROA of a company, the net income to the total assets of that business firm for a certain period can be easily understood. Because of that reason, each business prefers to secure a higher ROA as an implication of better efficiency of using the assets of the company. ROA (Return on Assets) has been calculated as net income divided by total assets.

\subsection{Independent Variables}

\subsection{Firm-Specific Factors}

- Firm Size: The natural log of total assets of each company has been chosen as one of the firm-specific independent variables. The percentage change in assets gives a clear view of understanding the impact and previous studies followed a similar approach too. The size of a firm creates a huge impact on the profitability of the firm. Because of higher size, a company gets more benefits to maximize its profit.

- Expense to Revenue Ratio: The expense to revenue ratio of a firm indicates the overall health of a business firm. A lower expense to revenue ratio indicates more profit potentiality of that business firm. Thus lower expense to revenue ratio is desired because it indicates that the expenses are minimized in comparison with the revenues.

- Leverage: Leverage indicates the usage of the total debt of a firm to its market value or the book value of the assets. The higher interest burden is created when a company absorbs more leveraged debt. Leverage creates an active impact on the profitability of the business firm by using both equity and debt financing in the capital structure.

- Age: The age of a firm positively impacts on its operations because of higher efficiency in managing costs and increasing revenues. Thus the age of the business firm is supposed to impact the firm's profitability positively. The year of commencement of business operations has been chosen as the beginning year of business. Thus age has been calculated from the year of commencement of business operations. The natural log of the age of each business firm has been taken as an independent variable for the study.

\subsubsection{Macroeconomic Factors}

- Inflation: Inflation creates an influence on all aspects of the economy. The business activities of any business firm are impacted by inflation. Inflation causes an increase in interest rate when there is a sharp rise in the inflation rate. Thus the profitability of the business firm is negatively impacted.

- GDP Growth Rate: The economic growth of any economy can be understood by the GDP growth rate. It provides an understanding of the market potential from the macro aspect. GDP growth rate creates an active influence on the profitability of the business firm. 
- Real Interest Rate: The deduction of the inflation rate from the nominal interest rate indicates the real interest rate. It is one kind of measurement to understand the positive change in the purchasing power of the lender while receiving the money from borrowers' repayment of interest and loan. Higher real interest rate increases the cost of borrowing of the business firms which reduces the profitability of the firms.

\subsubsection{Operational Definition}

Table I. List of Operational Variables

\begin{tabular}{lll}
\hline Variable & Notation & Definition \\
\hline Dependent Variable & & \\
\hline Return on Assets & ROA & Net Income / Total Asset \\
\hline Independent Variables & & \\
\hline Firm Size & LN Firm Size & Natural Log of Total Asset \\
\hline Expense to Revenue & Expense to Revenue & Operating Expense / Sales Revenue \\
\hline Leverage & Leverage & Total Liability/ Total Asset \\
\hline Age & LN Age & Natural Log of Age \\
\hline Inflation & Inflation & (CPIt - CPIt-I)/ CPIt-I \\
\hline GDP Growth Rate & GDP Growth Rate & (GDPt - GDPt-I)/GDPt-I \\
\hline Real Interest Rate & Real Interest Rate & Nominal Interest Rate - Inflation Rate \\
\hline
\end{tabular}

\subsection{The Hypotheses}

The hypotheses, which has been assumed for the seven independent variables. If the variable is statistically significant, we will accept the hypothesis for this variable. The coefficient sign for each variable indicates our expectation. Again, this hypothesis can be accepted partially if the variable is mildly insignificant with an expected coefficient. For any case out of these, the hypothesis will be rejected.

Table 2. List of Hypotheses

\begin{tabular}{cl}
\hline Hypothesis & \multicolumn{1}{c}{ Description } \\
\hline $\mathrm{H}_{\mathrm{I}}$ & Profitability is positively and significantly correlated to firm size \\
\hline $\mathrm{H}_{2}$ & Profitability is negatively and significantly correlated to expense to revenue ratio \\
\hline $\mathrm{H}_{3}$ & Profitability is negatively and significantly correlated to leverage \\
\hline $\mathrm{H}_{4}$ & Profitability is positively and significantly correlated to the age of a firm \\
\hline $\mathrm{H}_{5}$ & Profitability is negatively and significantly correlated to inflation \\
\hline $\mathrm{H}_{6}$ & Profitability is positively and significantly correlated to GDP growth rate \\
\hline $\mathrm{H}_{7}$ & Profitability is negatively and significantly correlated to the real interest rate \\
\hline
\end{tabular}

\subsection{Model of the Study}

To understand the relationship between the dependent variable and the independent variables, the study was attempted. The model of this study is given below:

$\mathrm{ROA}=\boldsymbol{\beta} 0+\boldsymbol{\beta} \mathrm{I}^{*} \mathrm{LN}$ Firm Size $+\boldsymbol{\beta} 2^{*}$ Expense to Revenue $+\boldsymbol{\beta} 3^{*}$ Leverage $+\boldsymbol{\beta} 4^{*} \mathrm{LN}$ Age $+\boldsymbol{\beta} 5^{*}$ Inflation $+\boldsymbol{\beta} 6^{*} \mathrm{GDP}$ Growth Rate $+\boldsymbol{\beta} 7^{*}$ Real Interest Rate $+\varepsilon$ it

The ROA (Return on Assets) in the above-mentioned equation indicates the profitability; $\beta 0$ indicates the constant of this model. $\beta$ I, $\beta 2 \ldots \beta$ are the coefficients to be estimated according to the variables and $\varepsilon i$ indicates the error term of this equation and the $t$ indicates the specific period. 
4. Empirical Results and Discussion

4.I Descriptive Statistics

The descriptive statistics that include average, minimum, maximum, and standard deviation of all variables is represented in the following table:

Table 3. Descriptive Statistics

\begin{tabular}{lcccc}
\hline \multicolumn{1}{c}{ Variable } & Mean & St. Dev. & Minimum & Maximum \\
\hline ROA & $5.74 \%$ & 0.17 & $-46 \%$ & $\mathrm{I} 60 \%$ \\
\hline Firm Size (in BDT million) & $4 \mathrm{I} 93$ & $4 \mathrm{I} 57$ & $\mathrm{I} 7$ & $\mathrm{I} 97 \mathrm{I} 4$ \\
\hline LN Firm Size & $2 \mathrm{I} .24$ & $\mathrm{I} .92$ & $\mathrm{I} 6.66$ & 23.7 \\
\hline Expense to Revenue & $7.67 \%$ & 0.13 & $\mathrm{I} .00 \%$ & $\mathrm{I} 3 \mathrm{I} \%$ \\
\hline Leverage & 0.58 & $0.2 \mathrm{I}$ & 0.17 & 0.98 \\
\hline Age (in years) & $2 \mathrm{I} .09$ & $\mathrm{I} 2.97$ & 2 & 55 \\
\hline LN Age & 2.87 & 0.62 & 0.69 & $4.0 \mathrm{I}$ \\
\hline Inflation & $6.38 \%$ & 0.02 & $2.01 \%$ & $\mathrm{I} 1.40 \%$ \\
\hline GDP Growth Rate & $6.05 \%$ & 0.01 & $3.83 \%$ & $7.86 \%$ \\
\hline Real Interest Rate & $5.78 \%$ & 0.02 & $3.07 \%$ & $9.26 \%$ \\
\hline
\end{tabular}

\subsection{Correlation}

The level of correlation among the variables used in multivariate regression analysis is shown in Table 4. The correlation between the variables is not so strong which suggests that there exists no multicollinearity problem among the variables.

Table 4. Correlation Matrix

\begin{tabular}{|c|c|c|c|c|c|c|c|c|}
\hline Variable & {$[\mathrm{I}]$} & {$[2]$} & {$[3]$} & {$[4]$} & {$[5]$} & {$[6]$} & {$[7]$} & {$[8]$} \\
\hline ROA & 1.00 & & & & & & & \\
\hline LN Firm Size & 0.05 & 1.00 & & & & & & \\
\hline Expense to Revenue & -0.07 & -0.28 & 1.00 & & & & & \\
\hline Leverage & -0.25 & -0.06 & 0.05 & 1.00 & & & & \\
\hline LN Age & -0.03 & $-0.0 \mathrm{I}$ & $-0 . \mathrm{II}$ & 0.33 & 1.00 & & & \\
\hline Inflation & -0.25 & -0.03 & 0.00 & 0.12 & 0.18 & 1.00 & & \\
\hline GDP Growth Rate & -0.03 & 0.13 & 0.14 & 0.02 & 0.32 & 0.28 & 1.00 & \\
\hline Real Interest Rate & 0.24 & -0.12 & -0.10 & -0.10 & -0.36 & -0.43 & -0.72 & 1.00 \\
\hline
\end{tabular}

\subsection{Multicollinearity}

The VIF (Variance Inflation Factor) is a great measurement tool for multicollinearity among the variables. The mean VIF of the test shown in Table 5 is 1.54 , which indicates that multicollinearity is not a problem for the dataset of this study.

Table 5. Multicollinearity

\begin{tabular}{lll}
\hline \multicolumn{1}{c}{ Variable } & VIF & I/VIF \\
\hline LN Firm Size & I.I5 & 0.87 \\
\hline Expense to Revenue & I.I9 & 0.84 \\
\hline Leverage & I.I5 & 0.87 \\
\hline LN Age & I.36 & 0.74 \\
\hline Inflation & I.26 & 0.79 \\
\hline
\end{tabular}




\begin{tabular}{lll}
\hline GDP Growth Rate & $2.2 \mathrm{I}$ & 0.45 \\
\hline Real Interest Rate & 2.48 & 0.40 \\
\hline Mean VIF & 1.54 & \\
\hline
\end{tabular}

\subsection{Methods for Data Analysis}

The dataset for our model is a panel dataset. Between the fixed effects model and the random-effects model, we will analyze which model is appropriate for our study by conducting the Hausman test. Stata/MP I3 software is used for conducting and specifying this study. The acceptance level of significance is $1 \%, 5 \%$, and $10 \%$ based on the outcome.

\subsection{Results and Discussions}

For deciding the appropriate model between the fixed effects model and the random-effects model, the Hausman test has been applied.

Table 6. Hypothesis for the Hausman Test

\begin{tabular}{ll}
\hline Hypothesis & Description \\
\hline Null & Random effects model is appropriate \\
\hline Alternative & Random effects model is not appropriate \\
\hline
\end{tabular}

The output of the Hausman test is given in the table below:

Table 7. Hausman Test

\begin{tabular}{lc}
\hline \multicolumn{2}{c}{ Results For Hausman Test } \\
\hline Chi-Square Statistic & 2.6 \\
\hline Chi-Square deg. f. & 7 \\
\hline Prob. & 0.919 \\
\hline
\end{tabular}

From the result of the Hausman test, the null hypothesis cannot be rejected. Thus the estimated model for this study will be based on random effects.

Table 8. Estimation Using Random Effects

\begin{tabular}{lcccc}
\hline \multicolumn{1}{c}{ Variable } & Coefficients & Std. Err. & z-statistic & p-value \\
\hline Constant & -0.3988 & $0.3 \mathrm{I}$ & -1.27 & 0.205 \\
\hline LN Firm Size & 0.0027 & 0.01 & 0.32 & 0.753 \\
\hline Expense to Revenue & -0.0457 & 0.13 & -0.36 & 0.718 \\
\hline Leverage & -0.1870 & 0.08 & -2.38 & $0.017^{\text {t }}$ \\
\hline LN Age & 0.0350 & 0.03 & 1.19 & 0.234 \\
\hline Inflation & -1.2634 & 0.83 & -1.52 & 0.129 \\
\hline GDP Growth Rate & 4.3450 & 2.44 & 1.78 & $0.075^{*}$ \\
\hline Real Interest Rate & 4.0040 & 1.57 & 2.55 & $0.010^{\text {th }}$ \\
\hline
\end{tabular}

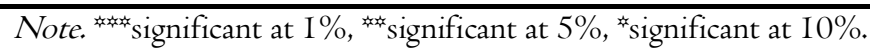

From the output given above, it is found that real interest rate, leverage, and GDP growth rate are statistically significant at $1 \%, 5 \%$, and $10 \%$ level of significance consecutively. For firm-specific factors, firm size and age have a positive impact on ROA where expense-to-revenue and leverage have negative impacts on ROA. For macroeconomic variables; we have found that ROA is influenced by real interest rate and GDP growth rate positively and by inflation negatively. The R-Squared 
value is within $18.09 \%$, between $38.82 \%$, and overall $17.69 \%$. The p-value of goodness of fit test (chi-square) is 0.0037 which is less than 0.05 indicates the model is strong.

Table 9. Decisions of Hypotheses Acceptance or Rejection

\begin{tabular}{clcccc}
\hline Hypothesis & \multicolumn{1}{c}{ Variable } & $\begin{array}{c}\text { Obtained } \\
\text { Significance }\end{array}$ & Expected Impact & Obtained Impact & Result \\
\hline $\mathrm{H}_{\mathrm{I}}$ & LN Firm Size & Insignificant & Positive & Positive & Accepted \\
\hline $\mathrm{H}_{2}$ & Expense to Revenue & Insignificant & Negative & Negative & Accepted \\
\hline $\mathrm{H}_{3}$ & Leverage & Significant & Negative & Negative & Accepted \\
\hline $\mathrm{H}_{4}$ & LN Age & Insignificant & Positive & Positive & Accepted \\
\hline $\mathrm{H}_{5}$ & Inflation & Insignificant & Negative & Negative & Accepted \\
\hline $\mathrm{H}_{6}$ & GDP Growth Rate & Significant & Positive & Positive & Accepted \\
\hline $\mathrm{H}_{7}$ & Real Interest Rate & Significant & Negative & Positive & Rejected \\
\hline
\end{tabular}

Through conducting the study, we found that firm size, age, real interest rate, and GDP growth rate have positive impacts on profitability. Expense-to-revenue, leverage, and inflation have negative impacts on profitability. The firm size helps the firm to increase its profitability by expanding its capacity more efficiently. The findings of the study show positive impact on profitability supporting Prasetyantoko and Rachmadi (2008), Khan et al. (2018), Ehi-Oshio et al. (2013), Zaid et al. (2014), and Al-Jafari and Samman (20I5) but varying from Goddard, Tavakoli, and Wilson (2005) and Aparna (20I5). The higher expense to revenue ratio of the firm indicates lower profitability. Expense to revenue ratio has negative impact on profitability partially supporting (Burja, 20II). Leverage in this study is calculated by dividing total liabilities to the total assets of the firm. The result show significant negative impact on profitability as higher liability in a business firm reduces profitability supporting Khan et al. (2018), Aparna (20I5), Prempeh et al. (2018) but varying from Ehi-Oshio et al. (2013), Maroa and Kioko (2016), and Egbunike and Okerekeoti (2018).

Business firm learns how to minimize costs and maximize profits with time. Thus, the age of the firm creates an active impact on profitability. The positive impact of age on profitability supports Majumdar (1997) but varies from Coad et al. (2010), Hirsch and Hartmann (2014), and Pervan \& Curak (2016). Higher inflation causes an increase in the nominal interest rate and causes an increase in the cost of borrowing. Thus, the findings also indicate a negative impact on profitability as inflation leads to a reduction on the profitability of the firms. The result supports Vatavu (20I4) and Egbunike and Okerekeoti (2018) but varies from Pervan et al. (2019) When an economy grows as per GDP, it creates more opportunities for the firms to make more profits by expanding the market demand of the products through infrastructure and development projects. Thus the impact of GDP growth rate is significantly positive on profitability of the cement industry supporting Egbunike and Okerekeoti (2018), Hassan and Muniyat (2019). Real interest has significant positive impact on profitability supporting Demir (2007) but varying Alper and Anbar (201 I).

\section{Conclusion}

After conducting the study through secondary data, the findings revealed that leverage as a firm-specific variable and GDP growth rate and real interest rate as macroeconomic variables have significant impact on the profitability. The results show that firm size, age, GDP growth rate, and real interest rate have positive impact while expense to revenue ratio, leverage, and inflation have negative impact on the profitability of the firms under cement industry of Bangladesh. Thus after conducting a thorough analysis of the factors influencing the profitability of the said industry, the study found a significant relationship regarding both firm-specific and macro-economic factors. The cement industry of Bangladesh has become one of the fastest growing sectors in recent years. Further research may be conducted to measure the impacts of firm-specific and macroeconomic factors in determining the profitability for other industries too. In this study, only listed companies under the stock exchanges have been considered. Hence, all cement companies in Bangladesh can be considered for further study by other researchers.

\section{Recommendations}

By considering the statistical significance, managers and policymakers of the cement industry need to take essential actions regarding the enhancement of financial performance. As in the recent years, multinational cement companies are expanding their capacity despite having unutilized facilities in anticipation of increasing demands, the government should take necessary steps to promote development in urbanization, real estate development, and government projects by local cement companies. Business firms under cement industry should prefer equity financing instead of debt financing. Business firms should design their sales 
forecasts according to the GDP growth rate movement and the real interest rate in the economy as both factors have significant positive impact on profitability. New technologies need to be adopted to improve the operational efficiencies of the firms.

\section{References}

Agustinus, P., \& Rachmadi, P. (2008). Determinants of corporate performance of listed companies in Indonesia.MPRA Paper.

Akben-Selcuk, E. (2016). Does Firm Age Affect Profitability? Evidence from turkey. International Journal of Economic Sciences, 5(3), I-9.

Al-Jafari, M. K., \& Samman, H. A. (2015). Determinants of profitability: evidence from industrial companies listed on Muscat Securities Market. Rev. Eur. Stud., 7, 303.

Alper, D., \& Anbar, A. (20II). Bank Specific and Macroeconomic Determinants of Commercial Bank Profitability: Empirical Evidence from Turkey. Business And Economics Research Journal, 2(2), I39-I52.

Ani, W. U., Ugwunta, D. O., Ezeudu, I. J., \& Ugwuanyi, G. O. (20I2). An empirical assessment of the determinants of bank profitability in Nigeria: Bank characteristics panel evidence. Journal of Accounting and Taxation, 4(3), 38-43.

Aparna, K. (2015). Determinants of profitability-a firm-level study of steel authority of India Limited (SAIL). Joumal of Business Management \& Social Sciences Research (JBM\&SSR), 4(I2), I-4.

Asimakopoulos, I., Samitas, A., \& Papadogonas, T. (2009). Firm-specific and economy-wide determinants of firm profitability: Greek evidence using panel data. Managerial Finance, 35(II), 930-939.

Bangladesh revises export target for cement in FY20. (2019). Retrieved 26 March 2020, from https://www.cemnet.com/News/story/167208/bangladesh-revises-export-target-for-cement-in-fy20.html

Bashar, S. M., \& Islam, M. I. (20I4). Determinants of profitability in the pharmaceutical industry of Bangladesh. Journal of SUB, 5(I), 56-76.

Batra, R., \& Kalia, A. (2016). Rethinking and redefining the determinants of corporate profitability. Global Business Review, I7(4), 92I-933.

Booth, L., Aivazian, V., Demirguc-Kunt, A., \& Maksimovic, V. (200I). Capital structures in developing countries. The journal of finance, 56(I), 87-I30.

Burja, C. (20I I). Factors Influencing The Companies' Profitability. Annales Universitatis Apulensis Series Oeconomica, 2(I3), 2I5-224. doi: I0.29302/oeconomica.20II.I3.2.3

Cement in Bangladesh: Building a Concrete Future - Light Castle Partners. (2020). Retrieved 27 March 2020, from https://www.lightcastlebd.com/insights/2019/03/20/cement-in-bangladesh-building-a-concretefuture\#: :text=Currently\%20in\%20Bangladesh\%20there\%20are,price \%20and\%20quality\%20\%5BI\%5D.

Coad, A., Segarra-Blasco, A., \& Teruel, M. (2010). Like milk or wine: Does firm performance improve with age? Structural Change and Economic Dynamics, 24,173-189. https://doi.org/I0.1016/j.strueco.2012.07.002

Company Listing by Industry. (2020). Retrieved 28 March 2020, from https://www.dsebd.org/companylistbyindustry.php?industryno=2I

Demir, F. (2007). Determinants of manufacturing firm profitability under uncertainty and macroeconomic volatility: Evidence from an emerging market. White Paper Of Department Of Economics, University Of Oklahoma, I-34.

Doğan, M. (2013). Does firm size affect the firm profitability? Evidence from Turkey. Research Journal of Finance and Accounting, 4(4), 53-59.

EBL Securities Ltd. (2019). Bangladesh Cement Industry: Resilient; Better Days Await (pp. I-27). Dhaka: EBL Securities Ltd. Retrieved $\quad$ from http://www.eblsecurities.com/AM_Resources/AM_ResearchReports/SectorReport/Comprehensive\%20Review\% 20on\%20Bangladesh\%20Cement\%20Industry,\%20August\%202019.pdf

Egbunike, C. F., \& Okerekeoti, C. U. (2018). Macroeconomic factors, firm characteristics and financial performance. Asian Journal of Accounting Research,3(2), I42-I68.

Ehi-Oshio, O. U., Adeyemi, A., \& Enofe, A. O. (2013). Determinants of corporate profitability in developing economies. European Journal of Business and Management, 5(I6), 42-50.

Fukao, K., Ito, K., Kabe, S., Liu, D., \& Takeuchi, F. (2006). Are Japanese firms failing to catch up in localization? An empirical analysis based on affiliate-level data of Japanese firms and a case study of the automobile industry in China. Discussion Paper Series No. I9I, Hitotsubashi University Repository.

Gyamerah, A. I., \& Amoah, B. (2015). Determinants of Bank Profitability in Ghana. International Journal of Accounting and Financial Reporting, 5(I), 173-187.

Goddard, J., Tavakoli, M., \& Wilson, J. O. (2005). Determinants of profitability in European manufacturing and services: evidence from a dynamic panel model. Applied Financial Economics, I5(18), I269-I282.

Hansen, G. S., \& Wernerfelt, B. (1989). Determinants of firm performance: The relative importance of economic and organizational factors. Strategic management journal, IO(5), 399-4I I. 
Hassan, S. R., \& Muniyat, S. (2019). Factors Influencing the Profitability of Pharmaceutical Companies in Bangladesh. International Conference on Business and Management, 770-773.

Hirsch, S., Schiefer, J., Gschwandtner, A., \& Hartmann, M. (20I4). The determinants of firm profitability differences in EU food processing. Journal of Agricultural Economics, 65(3), 703-72I.

Ifeduni A.S. \& Charlse O (2018). The determinants of profitability of manufacturing firms in Nigeria. International Journal of Economics, Commerce and Management. 6(4), 479-493.

Jensen, M. C. (1986). Agency costs of free cash flow, corporate finance, and takeovers. The American economic review, $76(2)$, 323-329.

Kester, W. C. (1986). Capital and ownership structure: A comparison of United States and Japanese manufacturing corporations. Financial management, 5-16.

Khan, T., Shamim, M., \& Goyal, J. (2018). Panel data analysis of profitability determinants: Evidence from Indian telecom companies. Theoretical Economics Letters, 8(I5), 358I-3593.

Maja, P., Pervan, I., \& Ćurak, M. (2016, January). Does business success enhance with firm's age? Case of Croatian food manufacturing industry. In Proceedings of The 27th International Business Information Management Association Conference (p. 3094).

Majumdar, S. K. (1997). The impact of size and age on firm-level performance: some evidence from India. Review of industrial organization, I2(2), 23I-24I.

Maroa, G. J., \& Kioko, W. C. (2016). Determinants of profitability of agricultural firms listed at the Nairobi Securities Exchange, Kenya. International Journal of Economics, Commerce and Management, 4(9), 225-235.

Mauri, A. J., \& Michaels, M. P. (1998). Firm and industry effects within strategic management: An empirical examination. Strategic management journal, I9(3), 2I I-2I9.

Mirza, S. A., \& Javed, A. (2013). Determinants of financial performance of a firm: Case of Pakistani stock market. Journal of economics and International Finance, 5(2), 43-52.

Myers, S.C. \& Majluf, N.S. (I984). Corporate financing and investment decisions when firms have information that investors do not have. Journal of financial economics. I3(2), I87-22I.

Nanda, S., \& Panda, A. K. (2018). The determinants of corporate profitability: an investigation of Indian manufacturing firms. International Journal of Emerging Markets. I3(I), 66-86.

Nunes, P. J. M., Serrasqueiro, Z. M., \& Sequeira, T. N. (2009). Profitability in Portuguese service industries: a panel data approach. The Service Industries Journal, 29(5), 693-707.

Pervan, M., Pervan, I., \& Ćurak, M. (2019). Determinants of firm profitability in the Croatian manufacturing industry: evidence from dynamic panel analysis. Economic research-Ekonomska istraživanja, 32(I), 968-98I.

Prasetyantoko, A., \& Rachmadi, P. (2008). Determinants of corporate performance of listed companies in Indonesia. University Library of Munich, Germany.

Pratheepan, T. (20I4). A Panel Data Analysis of Profitability Determinants: Empirical Results from Sri Lankan Manufacturing Companies. International Journal of Economics, Commerce and Management, 2(I2), I-9.

Prempeh, K., Sekyere, A. M., \& Amponsah Addy, E. K. (2018). A multivariate analysis of determinants of profitability: Evidence from selected manufacturing companies listed on the Ghana stock exchange. Available at SSRN 3096972.

Rahman, M. (2018). Bangladesh to be 26th largest economy. The Daily Star. Retrieved from https://www.thedailystar.net/business/news/bangladesh-be-26th-largest-economy-I 642432

Rajan, R. G., \& Zingales, L. (I995). What do we know about capital structure? Some evidence from international data. The journal of Finance, 50(5), I42I-1460.

Samarakoon, L. P. (1999). The capital structure of Sri Lankan companies. Sri Lankan journal of management, 4(I\&2), I8-30.

Schmalensee, R. (1985). Do markets differ much?. The American economic review, 75(3), 34I-35I.

Shehab, M. (2019) Building a Concrete Future. Retrieved from: https://www.lightcastlebd.com/insights/2019/03/20/cement-in-bangladesh-building-a-concrete-future

Sivathaasan, N., Tharanika, R., Sinthuja, M., \& Hanitha, V. (2013). Factors determining profitability: A study of selected manufacturing companies listed on Colombo Stock Exchange in Sri Lanka. European Journal of Business and management, 5(27), 99-107.

Stierwald, A. (2010). The causes of profit heterogeneity in large Australian firms. Working Paper No. 7/I0, Melbourne Institute of Applied Economic and Social Research, University of Melbourne, Melbourne.

Sufian, F. \& Chong, R.R. (2008). Determinants of bank profitability in a developing economy: empirical evidence from the Philippines. Asian Academy of Management Journal of Accounting \& Finance, 4(2), 480-492.

Tailab, M. (20I4). The effect of capital structure on profitability of energy American firms. International Journal of Business and Management Invention, 3(12), 54-6I. 
The Daily Star. (2019). Bangladesh second in South Asia in GDP growth: WB. Retrieved from https://www.thedailystar.net/business/bangladesh-second-gdp-growth-rate-country-in-south-asia-I8I3420

The World Bank Data. (2020). Retrieved 2I March 2020, from https://data.worldbank.org/country/BD

Titman, S., \& Wessels, R. (1988). The determinants of capital structure choice. The Journal of finance, 43(I), I-I9.

Tuhin, A. (2019). Bangladesh's cement industry booming. Retrieved 26 March 2020, from https://tbsnews.net/economy/bangladeshs-cement-industry-booming

Vătavu, S. (2014). The determinants of profitability in companies listed on the Bucharest stock exchange. Annals of the University of Petrosani Economics, I4(I), 329-338.

Yazdanfar, D. (20I3). Profitability determinants among micro firms: evidence from Swedish data. International Journal of Managerial Finance, $9(2)$, I5I-I60.

Zaid, M. N., Wan Muhd, F. I., \& Zulqernain, S. N. (20I4). The Determinants of Profitability: Evidence from Malaysian Construction Companies. 5th Asia-Pacific Business Research Conference. (pp. II3). Kuala Lumpur: Minister of Works Malaysia.

\section{Appendix A}

List of All the Listed Cement Companies on DSE and Chosen Data Period for the Study

\begin{tabular}{lcc}
\hline Companies & Year of Commencement & Data Period \\
\hline I. Aramit Cement Limited & I963 & 2000-2018 \\
\hline 2. Confidence Cement Ltd. & I99I & $2000-2018$ \\
\hline 3. Heidelberg Cement Bangladesh Ltd. & I998 & $2000-2018$ \\
\hline 4. LafargeHolcim Bangladesh Limited & I997 & $2006-2018$ \\
\hline 5. M I Cement Factory Limited & I994 & $2009-2018$ \\
\hline 6. Maghna Cement Mills Ltd. & I992 & 2000-2018 \\
\hline 7. Premier Cement Mills Limited & 200I & 2012-2018 \\
\hline
\end{tabular}

\section{Appendix B}

Data set for the Study

\begin{tabular}{|c|c|c|c|c|c|c|c|c|c|c|}
\hline $\begin{array}{l}\text { S.L } \\
\text { No. }\end{array}$ & Company & Year & $\mathrm{ROA}$ & $\begin{array}{l}\text { LN } \\
\text { Age }\end{array}$ & $\begin{array}{l}\text { LN } \\
\text { Size }\end{array}$ & $\begin{array}{l}\text { Expense to } \\
\text { Revenue }\end{array}$ & Leverage & Inflation & $\begin{array}{l}\text { GDP } \\
\text { Growth }\end{array}$ & $\begin{array}{l}\text { Real Int. } \\
\text { Rate }\end{array}$ \\
\hline $\mathrm{I}$ & $\bar{I}$ & 2000 & 1.60 & $3.6 \mathrm{I}$ & 19.80 & 0.056 & 0.509 & 0.022 & 0.053 & 0.090 \\
\hline 2 & $\mathrm{I}$ & $200 I$ & 0.05 & 3.64 & I9.9I & 0.022 & 0.543 & 0.020 & $0.05 \mathrm{I}$ & 0.093 \\
\hline 3 & $\mathrm{I}$ & 2002 & $-0.1 \mathrm{I}$ & 3.66 & 19.86 & 0.040 & 0.616 & 0.033 & 0.038 & 0.084 \\
\hline 4 & I & 2003 & -0.14 & 3.69 & 19.80 & 0.063 & 0.720 & 0.057 & 0.047 & 0.059 \\
\hline 5 & $\mathrm{I}$ & 2004 & -0.46 & $3.7 \mathrm{I}$ & 19.70 & 0.074 & $0.89 \mathrm{I}$ & 0.076 & 0.052 & 0.056 \\
\hline 6 & I & 2005 & -0.06 & 3.74 & 19.87 & 0.027 & 0.980 & 0.070 & 0.065 & 0.058 \\
\hline 7 & I & 2006 & $0.0 \mathrm{I}$ & 3.76 & 20.26 & 0.026 & 0.603 & 0.068 & 0.067 & 0.055 \\
\hline 8 & I & 2007 & 0.03 & 3.78 & 20.07 & $0.03 \mathrm{I}$ & 0.953 & $0.09 \mathrm{I}$ & 0.071 & 0.058 \\
\hline 9 & $\mathrm{I}$ & 2008 & 0.00 & $3.8 \mathrm{I}$ & 20.30 & 0.035 & 0.954 & 0.089 & 0.060 & 0.047 \\
\hline $\mathrm{IO}$ & I & 2009 & 0.08 & 3.83 & 20.39 & 0.038 & 0.907 & 0.054 & 0.050 & 0.061 \\
\hline II & I & 2010 & 0.08 & 3.85 & 20.70 & 0.044 & 0.865 & $0.08 \mathrm{I}$ & 0.056 & 0.047 \\
\hline $\mathrm{I} 2$ & I & 2011 & 0.04 & 3.87 & 20.97 & $0.05 \mathrm{I}$ & 0.858 & 0.1 I4 & 0.065 & $0.05 \mathrm{I}$ \\
\hline I3 & I & 2012 & 0.03 & 3.89 & 21.16 & 0.047 & 0.850 & 0.062 & 0.065 & 0.053 \\
\hline I4 & I & 2013 & 0.03 & $3.9 \mathrm{I}$ & 2I.I8 & 0.063 & 0.827 & 0.075 & 0.060 & 0.060 \\
\hline
\end{tabular}




\begin{tabular}{|c|c|c|c|c|c|c|c|c|c|c|}
\hline I5 & I & 2014 & 0.00 & 3.93 & 21.35 & 0.075 & 0.719 & 0.070 & $0.06 \mathrm{I}$ & 0.069 \\
\hline 16 & I & 2015 & 0.00 & 3.95 & 21.49 & 0.078 & 0.765 & 0.062 & 0.066 & 0.055 \\
\hline I7 & I & 2016 & 0.01 & 3.97 & 21.68 & 0.072 & 0.813 & 0.055 & $0.07 \mathrm{I}$ & 0.034 \\
\hline I8 & I & 2017 & -0.03 & 3.99 & 21.93 & 0.093 & 0.887 & 0.057 & 0.073 & 0.031 \\
\hline I9 & I & 2018 & 0.05 & $4.0 \mathrm{I}$ & 20.84 & 0.168 & 0.168 & 0.055 & 0.079 & 0.038 \\
\hline 20 & 2 & 2000 & 0.19 & 2.20 & 20.45 & $0.05 \mathrm{I}$ & 0.223 & 0.022 & 0.053 & 0.090 \\
\hline $2 \mathrm{I}$ & 2 & $200 \mathrm{I}$ & 0.16 & 2.30 & 20.72 & 0.045 & 0.305 & 0.020 & $0.05 \mathrm{I}$ & 0.093 \\
\hline 22 & 2 & 2002 & -0.02 & 2.40 & 21.22 & 0.080 & 0.267 & 0.033 & 0.038 & 0.084 \\
\hline 23 & 2 & 2003 & $0.0 \mathrm{I}$ & 2.48 & 2I.I4 & 0.062 & 0.622 & 0.057 & 0.047 & 0.059 \\
\hline 24 & 2 & 2004 & -0.03 & 2.56 & 20.66 & $0.07 \mathrm{I}$ & $0.35 \mathrm{I}$ & 0.076 & 0.052 & 0.056 \\
\hline 25 & 2 & 2005 & 0.02 & 2.64 & 20.78 & 0.038 & $0.4 \mathrm{I} 2$ & 0.070 & 0.065 & 0.058 \\
\hline 26 & 2 & 2006 & 0.03 & $2.7 \mathrm{I}$ & 20.97 & $0.03 \mathrm{I}$ & 0.270 & 0.068 & 0.067 & 0.055 \\
\hline 27 & 2 & 2007 & 0.05 & 2.77 & 20.82 & $0.03 \mathrm{I}$ & 0.377 & $0.09 \mathrm{I}$ & $0.07 \mathrm{I}$ & 0.058 \\
\hline 28 & 2 & 2008 & -0.02 & 2.83 & 20.87 & 0.030 & 0.456 & 0.089 & 0.060 & 0.047 \\
\hline 29 & 2 & 2009 & 0.06 & 2.89 & 21.57 & 0.036 & 0.196 & 0.054 & 0.050 & 0.061 \\
\hline 30 & 2 & 2010 & 0.07 & 2.94 & 21.90 & 0.036 & 0.195 & $0.08 \mathrm{I}$ & 0.056 & 0.047 \\
\hline $3 I$ & 2 & $201 \mathrm{I}$ & 0.05 & 3.00 & 22.04 & $0.03 \mathrm{I}$ & 0.327 & 0.114 & 0.065 & 0.051 \\
\hline 32 & 2 & 2012 & 0.07 & 3.04 & 22.13 & 0.029 & 0.389 & 0.062 & 0.065 & 0.053 \\
\hline 33 & 2 & 2013 & 0.08 & 3.09 & 22.25 & 0.035 & 0.359 & 0.075 & 0.060 & 0.060 \\
\hline 34 & 2 & 2014 & 0.04 & 3.14 & 22.34 & 0.039 & $0.43 \mathrm{I}$ & 0.070 & $0.06 \mathrm{I}$ & 0.069 \\
\hline 35 & 2 & 2015 & 0.06 & 3.18 & 22.44 & 0.045 & 0.443 & 0.062 & 0.066 & 0.055 \\
\hline 36 & 2 & 2016 & 0.07 & 3.22 & 22.55 & 0.093 & 0.468 & 0.055 & $0.07 \mathrm{I}$ & 0.034 \\
\hline 37 & 2 & 2017 & 0.06 & 3.26 & 22.77 & $0.13 \mathrm{I}$ & $0.5 \mathrm{IO}$ & 0.057 & 0.073 & 0.031 \\
\hline 38 & 2 & 2018 & 0.05 & 3.30 & 22.83 & 0.077 & 0.500 & 0.055 & 0.079 & 0.038 \\
\hline 39 & 3 & 2000 & 0.12 & 0.69 & 21.28 & 0.069 & $0.4 \mathrm{I} 2$ & 0.022 & 0.053 & 0.090 \\
\hline 40 & 3 & $200 \mathrm{I}$ & 0.12 & I.IO & 21.30 & 0.064 & $0.35 \mathrm{I}$ & 0.020 & $0.05 \mathrm{I}$ & $\overline{0.093}$ \\
\hline $4 \mathrm{I}$ & 3 & 2002 & 0.03 & I.39 & 21.26 & 0.097 & 0.308 & 0.033 & 0.038 & 0.084 \\
\hline 42 & 3 & 2003 & -0.01 & I.6I & 22.13 & 0.105 & 0.583 & 0.057 & 0.047 & 0.059 \\
\hline 43 & 3 & 2004 & 0.00 & 1.79 & 22.14 & 0.098 & 0.589 & 0.076 & 0.052 & 0.056 \\
\hline 44 & 3 & 2005 & 0.03 & 1.95 & 22.19 & 0.083 & 0.574 & 0.070 & 0.065 & 0.058 \\
\hline 45 & 3 & 2006 & 0.13 & 2.08 & 22.14 & 0.052 & 0.439 & 0.068 & 0.067 & 0.055 \\
\hline 46 & 3 & 2007 & 0.18 & 2.20 & 22.36 & 0.057 & 0.446 & $0.09 \mathrm{I}$ & $0.07 \mathrm{I}$ & 0.058 \\
\hline 47 & 3 & 2008 & 0.10 & 2.30 & 22.49 & 0.053 & 0.438 & 0.089 & 0.060 & 0.047 \\
\hline 48 & 3 & 2009 & 0.14 & 2.40 & 22.52 & 0.053 & 0.424 & 0.054 & 0.050 & 0.061 \\
\hline 49 & 3 & 2010 & 0.14 & 2.48 & 22.69 & 0.060 & 0.338 & $0.08 \mathrm{I}$ & 0.056 & 0.047 \\
\hline 50 & 3 & $20 I I$ & 0.09 & 2.56 & 22.80 & 0.058 & 0.343 & 0.114 & 0.065 & 0.051 \\
\hline $5 \mathrm{I}$ & 3 & 2012 & 0.14 & 2.64 & 22.94 & $0.05 \mathrm{I}$ & $0.3 \mathrm{I} 4$ & 0.062 & 0.065 & 0.053 \\
\hline 52 & 3 & 2013 & 0.14 & $2.7 \mathrm{I}$ & 23.10 & 0.067 & $0.30 \mathrm{I}$ & 0.075 & 0.060 & 0.060 \\
\hline 53 & 3 & 2014 & 0.12 & 2.77 & 23.04 & 0.069 & 0.359 & 0.070 & $0.06 \mathrm{I}$ & 0.069 \\
\hline 54 & 3 & 2015 & 0.14 & 2.83 & 23.00 & $0.08 \mathrm{I}$ & 0.409 & 0.062 & 0.066 & 0.055 \\
\hline 55 & 3 & 2016 & 0.15 & 2.89 & 23.04 & 0.087 & $0.45 \mathrm{I}$ & 0.055 & $0.07 \mathrm{I}$ & 0.034 \\
\hline
\end{tabular}




\begin{tabular}{|c|c|c|c|c|c|c|c|c|c|c|}
\hline 56 & 3 & 2017 & 0.09 & 2.94 & 22.89 & 0.099 & 0.462 & 0.057 & 0.073 & $0.03 \mathrm{I}$ \\
\hline 57 & 3 & 2018 & 0.09 & 3.00 & 22.74 & $0.50 \mathrm{I}$ & $0.5 \mathrm{I} 5$ & 0.055 & 0.079 & 0.038 \\
\hline 58 & 4 & 2006 & -0.05 & 2.20 & I6.66 & I.3I5 & 0.750 & 0.068 & 0.067 & 0.055 \\
\hline 59 & 4 & 2007 & -0.06 & 2.30 & 16.69 & 0.222 & 0.816 & $0.09 \mathrm{I}$ & $0.07 \mathrm{I}$ & 0.058 \\
\hline 60 & 4 & 2008 & 0.01 & 2.40 & I6.70 & 0.079 & 0.808 & 0.089 & 0.060 & 0.047 \\
\hline $6 \mathrm{I}$ & 4 & 2009 & 0.06 & 2.48 & I6.67 & 0.067 & 0.744 & 0.054 & 0.050 & 0.061 \\
\hline 62 & 4 & 2010 & -0.09 & 2.56 & I6.70 & 0.299 & 0.845 & $0.08 \mathrm{I}$ & 0.056 & 0.047 \\
\hline 63 & 4 & $20 \mathrm{II}$ & -0.12 & 2.64 & I6.74 & 0.073 & 0.652 & 0.114 & 0.065 & $0.05 \mathrm{I}$ \\
\hline 64 & 4 & 2012 & 0.14 & $2.7 \mathrm{I}$ & I6.72 & 0.078 & 0.557 & 0.062 & 0.065 & 0.053 \\
\hline 65 & 4 & 2013 & 0.13 & 2.77 & 16.76 & 0.094 & 0.420 & 0.075 & 0.060 & 0.060 \\
\hline 66 & 4 & 2014 & 0.14 & 2.83 & I6.80 & 0.080 & $0.33 \mathrm{I}$ & 0.070 & $0.06 \mathrm{I}$ & 0.069 \\
\hline 67 & 4 & 2015 & 0.08 & 2.89 & I6.85 & 0.094 & 0.306 & 0.062 & 0.066 & 0.055 \\
\hline 68 & 4 & 2016 & 0.07 & 2.94 & I6.86 & 0.008 & 0.267 & 0.055 & $0.07 \mathrm{I}$ & 0.034 \\
\hline 69 & 4 & 2017 & 0.02 & 3.00 & 16.89 & 0.120 & $0.29 \mathrm{I}$ & 0.057 & 0.073 & 0.031 \\
\hline 70 & 4 & 2018 & 0.03 & 3.04 & I7.II & 0.105 & $0.42 \mathrm{I}$ & 0.055 & 0.079 & 0.038 \\
\hline $7 \mathrm{I}$ & 5 & 2009 & 0.12 & $2.7 \mathrm{I}$ & 21.14 & 0.024 & $0.5 \mathrm{I} 3$ & 0.054 & 0.050 & 0.061 \\
\hline 72 & 5 & 2010 & 0.15 & 2.77 & 21.55 & 0.056 & 0.415 & $0.08 \mathrm{I}$ & 0.056 & 0.047 \\
\hline 73 & 5 & $201 \mathrm{I}$ & 0.06 & 2.83 & 22.67 & 0.055 & 0.282 & 0.II4 & 0.065 & 0.051 \\
\hline 74 & 5 & 2012 & 0.06 & 2.89 & 23.02 & 0.042 & 0.452 & 0.062 & 0.065 & 0.053 \\
\hline 75 & 5 & 2013 & 0.07 & 2.94 & 23.00 & 0.046 & 0.428 & 0.075 & 0.060 & 0.060 \\
\hline 76 & 5 & $20 I 4$ & 0.06 & 3.00 & 23.15 & 0.043 & 0.500 & 0.070 & $0.06 \mathrm{I}$ & 0.069 \\
\hline 77 & 5 & 2015 & 0.05 & 3.04 & 23.21 & 0.055 & $0.5 \mathrm{I} 3$ & 0.062 & 0.066 & 0.055 \\
\hline 78 & 5 & 2016 & 0.05 & 3.09 & 23.37 & 0.056 & 0.525 & 0.055 & $0.07 \mathrm{I}$ & 0.034 \\
\hline 79 & 5 & 2017 & 0.04 & 3.14 & 23.61 & 0.065 & 0.604 & 0.057 & 0.073 & 0.031 \\
\hline 80 & 5 & 2018 & 0.02 & 3.18 & 23.70 & 0.063 & 0.639 & 0.055 & 0.079 & 0.038 \\
\hline $8 \mathrm{I}$ & 6 & 2000 & 0.08 & 2.08 & 21.37 & 0.047 & 0.800 & 0.022 & 0.053 & 0.090 \\
\hline 82 & 6 & $200 \mathrm{I}$ & 0.08 & 2.20 & 21.56 & 0.032 & 0.794 & 0.020 & $0.05 \mathrm{I}$ & 0.093 \\
\hline 83 & 6 & 2002 & 0.03 & 2.30 & 21.66 & 0.035 & $0.80 \mathrm{I}$ & 0.033 & 0.038 & 0.084 \\
\hline 84 & 6 & 2003 & 0.01 & 2.40 & 21.61 & 0.018 & 0.777 & 0.057 & 0.047 & 0.059 \\
\hline 85 & 6 & 2004 & 0.01 & 2.48 & 21.59 & 0.020 & 0.738 & 0.076 & 0.052 & 0.056 \\
\hline 86 & 6 & 2005 & 0.03 & 2.56 & 21.67 & 0.016 & 0.740 & 0.070 & 0.065 & 0.058 \\
\hline 87 & 6 & 2006 & 0.02 & 2.64 & 21.59 & $0.02 \mathrm{I}$ & 0.778 & 0.068 & 0.067 & 0.055 \\
\hline 88 & 6 & 2007 & 0.04 & $2.7 \mathrm{I}$ & 21.78 & 0.023 & 0.784 & $0.09 \mathrm{I}$ & $0.07 \mathrm{I}$ & 0.058 \\
\hline 89 & 6 & 2008 & 0.01 & 2.77 & 21.79 & 0.028 & 0.803 & 0.089 & 0.060 & 0.047 \\
\hline 90 & 6 & 2009 & 0.04 & 2.83 & 21.92 & 0.038 & 0.797 & 0.054 & 0.050 & 0.061 \\
\hline $9 \mathrm{I}$ & 6 & 2010 & 0.01 & 2.89 & 22.01 & 0.035 & 0.815 & $0.08 \mathrm{I}$ & 0.056 & 0.047 \\
\hline 92 & 6 & $20 I I$ & 0.02 & 2.94 & 22.14 & 0.045 & 0.836 & 0.114 & 0.065 & $\overline{0.051}$ \\
\hline 93 & 6 & 2012 & 0.03 & 3.00 & 22.15 & $0.05 \mathrm{I}$ & 0.818 & 0.062 & 0.065 & 0.053 \\
\hline 94 & 6 & 2013 & 0.03 & 3.04 & 22.15 & 0.042 & $0.82 \mathrm{I}$ & 0.075 & 0.060 & 0.060 \\
\hline 95 & 6 & 2014 & 0.02 & 3.09 & 22.09 & 0.047 & 0.793 & 0.070 & 0.061 & 0.069 \\
\hline 96 & 6 & 2015 & 0.02 & 3.14 & 22.07 & 0.062 & $0.8 \mathrm{II}$ & 0.062 & 0.066 & 0.055 \\
\hline
\end{tabular}




\begin{tabular}{|c|c|c|c|c|c|c|c|c|c|c|}
\hline 97 & 6 & 2016 & 0.01 & 3.18 & 22.24 & 0.052 & 0.826 & 0.055 & $0.07 \mathrm{I}$ & 0.034 \\
\hline 98 & 6 & 2017 & $0.0 \mathrm{I}$ & 3.22 & 22.27 & 0.064 & 0.824 & 0.057 & 0.073 & $0.03 \mathrm{I}$ \\
\hline 99 & 6 & 2018 & $0.0 \mathrm{I}$ & 3.26 & 22.65 & 0.063 & 0.875 & 0.055 & 0.079 & 0.038 \\
\hline 100 & 7 & 2012 & 0.03 & 2.40 & $22.6 I$ & 0.047 & 0.658 & 0.062 & 0.065 & 0.053 \\
\hline IOI & 7 & 2013 & 0.06 & 2.48 & 22.86 & 0.017 & 0.621 & 0.075 & 0.060 & 0.060 \\
\hline I02 & 7 & 2014 & 0.05 & 2.56 & $23.0 \mathrm{I}$ & 0.050 & 0.663 & 0.070 & 0.061 & 0.069 \\
\hline I03 & 7 & 2015 & 0.04 & 2.64 & 23.03 & 0.055 & 0.663 & 0.062 & 0.066 & 0.055 \\
\hline I04 & 7 & 2016 & 0.06 & $2.7 \mathrm{I}$ & 23.11 & 0.066 & 0.613 & 0.055 & $0.07 \mathrm{I}$ & 0.034 \\
\hline 105 & 7 & 2017 & 0.05 & 2.77 & 23.07 & 0.070 & 0.586 & 0.057 & 0.073 & $0.03 \mathrm{I}$ \\
\hline I06 & 7 & 2018 & 0.07 & 2.83 & 23.33 & 0.052 & 0.664 & 0.055 & 0.079 & 0.038 \\
\hline
\end{tabular}

\section{Copyrights}

Copyright for this article is retained by the author(s), with first publication rights granted to the journal. This is an open-access article distributed under the terms and conditions of the Creative Commons Attribution license (http://creativecommons.org/licenses/by/4.0/). 